\title{
Atopic Dermatitis: Identification and Management of Complicating Factors
}

\author{
Risa Tamagawa-Mineoka *(D) and Norito Katoh \\ Department of Dermatology, Graduate School of Medical Science, Kyoto Prefectural University of Medicine, \\ 465 Kajii-cho, Kawaramachi-Hirokoji, Kamigyo-ku, Kyoto 602-8566, Japan; nkatoh@koto.kpu-m.ac.jp \\ * Correspondence: risat@koto.kpu-m.ac.jp; Tel.: +81-75-251-5586
}

Received: 23 March 2020; Accepted: 10 April 2020; Published: 11 April 2020

\begin{abstract}
Atopic dermatitis (AD) is a chronic relapsing inflammatory skin disease, associated with impaired skin barrier function and an atopic background. Various complicating factors, such as irritants, aeroallergens, food, microbial organisms, contact allergens, sweat, and scratching can induce the development of AD symptoms. Irritants, including soap/shampoo and clothes, can cause itching and eczematous lesions. In addition, young children with AD tend to become sensitized to eggs, milk, or peanuts, while older children and adults more often become sensitized to environmental allergens, such as house dust mites (HDM), animal dander, or pollen. Serum-specific IgE levels and skin prick test reactions to food tend to show high negative predictive values and low specificity and positive predictive values for diagnosing food allergy. On the other hand, AD adult patients tend to have severe skin symptoms and exhibit high HDM-specific IgE levels. Microbial organisms, e.g., Staphylococcus aureus and Malassezia furfur, might contribute to the pathogenetic mechanisms of AD. While sweat plays a major role in maintaining skin homeostasis, it can become an aggravating factor in patients with AD. Furthermore, scratching often exacerbates eczematous lesions. Several patient-specific complicating factors are seen in most cases. The identification and management of complicating factors are important for controlling AD.
\end{abstract}

Keywords: atopic dermatitis; complicating factors; aggravating factors; triggering factors; irritants; aeroallergens; food; microbial organisms; contact allergens; sweat; scratching

\section{Introduction}

Atopic dermatitis (AD) is a common, chronic relapsing inflammatory, multifactorial skin disease, which is characterized by intense pruritus [1-3]. It affects up to $20 \%$ of children and $1-3 \%$ of adults [4]. The mechanisms responsible for the onset and aggravation of $\mathrm{AD}$ involve skin barrier dysfunction and an atopic background. In patients with $\mathrm{AD}$, the functions of the intercellular lipids of the stratum corneum are impaired because of abnormal reductions in ceramide levels [5,6]. The horny cell layer, which consists of keratin and filaggrin, is structurally tough. A loss-of-function mutation in filaggrin and filaggrin deficiency related to inflammation have been observed in patients with $\operatorname{AD}[7,8]$. A reduction in skin barrier function might allow stimuli and allergens to penetrate the skin more easily. Interleukin (IL)-33, IL-25, and thymic stromal lymphopoietin (TSLP), which are released from epidermal keratinocytes upon exposure to proteases, allergens, infections, or tissue damage, induce type- 2 immune reactions, leading to the induction of allergen-specific $\operatorname{IgE}$ antibody production.

With regard to the treatment of $\mathrm{AD}$, topical corticosteroids and topical calcineurin inhibitors are the main treatments for inflammation, whereas the topical application of moisturizers is used to treat cutaneous barrier dysfunction $[1,2,9]$. Systemic treatment, e.g., oral cyclosporin and UV irradiation, is an option for severe refractory cases $[1,2,10]$. Several patient-specific complicating factors are seen in 
most cases. It is important to identify such factors and establish strategies to combat them. This review concisely discusses the identification and management of the complicating factors of AD.

\section{Irritants}

Skin barrier function is impaired in patients with AD. Therefore, there is a tendency for itching and eczematous lesions to develop after AD patients come into contact with irritants (Table 1). To prevent this, AD patients should cleanse their skin gently to get rid of any dirt. Regarding the $\mathrm{pH}$ of the corneal layer, a subacidic state is considered healthy. A barrier-dependent increase in $\mathrm{pH}$, e.g., due to the use of neutral-to-alkaline soaps, leads to a reduction in skin barrier function [11]. Soaps and shampoos that contain non-irritant ingredients can be used instead. Furthermore, residual soap and shampoo can induce irritant dermatitis. Therefore, it is important to fully wash away soap/shampoo. Synthetic fabrics and wool also tend to produce itching and irritate the skin [1,2,12-14]. A previous study has shown that the irritative capacity of synthetic shirts is significantly higher in patients with $A D$, while cotton shirts are tolerated best [12]. Thus, AD patients should select non-irritating clothes.

Table 1. Management of irritants.

\begin{tabular}{ccc}
\hline Irritants & Management & References \\
\hline Scrubbing the body & Wash the body gently without using nylon towels & {$[1,2]$} \\
\hline Soap and shampoo & Use non-irritating soap and shampoo & {$[1,2,7]$} \\
\hline Irritating clothes (e.g., wool-based clothes) & Choose suitable non-irritating clothes (e.g., cotton clothes) & {$[1,2,8,9]$} \\
\hline Hair & Tie hair up & {$[1]$} \\
\hline Saliva (during infancy) & Wash away or wipe off & {$[1]$} \\
\hline
\end{tabular}

\section{Aeroallergens}

\subsection{House Dust Mites (HDM)}

Aeroallergens, such as HDM, animal dander, and pollen, can lead to the exacerbation of AD. HDM is one of the main allergens blamed for household dust allergies [15]. The most frequently responsible mites are Dermatophagoides pteronyssinus (European house dust mite) and D. farinae (American house dust mite), which produce various allergens in their bodies and feces. Currently, there are $>30$ defined mite allergens (Table 2) [16]. It is considered that the most clinically important allergens are Der $\mathrm{p} 1$ and Der $\mathrm{p} 2$ from D. Pteronyssinus and Der $\mathrm{f} 1$ and Der $\mathrm{f} 2$ from $D$. farinae. The HDM allergen Der $\mathrm{p} 1$ is found at concentrations of $0.05-0.2 \mathrm{ng} / \mathrm{m}^{3}$ in inhalable indoor air [17].

Table 2. Representative allergens derived from D. Pteronyssinus and D. farina [16].

\begin{tabular}{ccc}
\hline Allergen & Biochemical Name & Molecular Weight (kDa) \\
\hline Der p 1/Der f 1 & Cysteine protease & 24 and 27 \\
\hline Der p 2/Der f 2 & NPC2 family & 15 \\
\hline Der p 3/Der f 3 & Trypsin & 31 and 29 \\
\hline Der p 4/Der f 4 & Alpha-amylase & 60 and 57.9 \\
\hline Der p 5/Der f 5 & Unknown & 14 and 15.5 \\
\hline Der p 6/Der f 6 & Chymotrypsin & 25 \\
\hline Der p 7/Der f 7 & Bactericidal permeability-increasing like protein & 26,30, and 31 \\
\hline Der p 8/Der f 8 & Glutathione S-transferase & 27 and 32 \\
\hline Der p 9 & Collagenolytic serine protease & 29 \\
\hline Der p 10/Der f 10 & Tropomyosin & 36 and 37 \\
\hline
\end{tabular}


Patients with AD frequently exhibit high total serum IgE levels and environmental allergen-specific IgE. In addition, skin prick testing and atopic patch testing (APT) produce positive reactions to these allergens in AD patients [18-20]. APT has been used to test for delayed-type hypersensitivity/eczematous reactions. Langerhans cells from AD patients have been shown to have an increased capacity to present HDM allergen antigens to $\mathrm{T}$ cells via the high affinity receptor for IgE (Fc\&RI) [21,22], suggesting that IgE-mediated delayed-type hypersensitivity reactions to HDM allergens are associated with the pathogenesis of AD [23-25]. It has been reported that AD patients that experience delayed-type hypersensitivity reactions tend to have severe skin symptoms and exhibit high total IgE levels and HDM-specific IgE levels [17]. In addition, the positivity rate of patch tests performed with HDM antigens was found to be significantly higher in patients that mainly had eczema lesions on exposed areas, such as the hands, forearms, head, and neck, than in patients who also had eczema lesions on non-exposed areas [26].

Even when a patient's serum levels of HDM-specific IgE are increased and strong reactions to HDM are seen during skin tests, whether exposure to HDM is considered to be an aggravating factor in that case should be determined based on the patient's episodes and symptoms [1]. For example, it should be clarified whether the patient develops symptoms of immediate-type hypersensitivity reactions, i.e., wheals, conjunctival or rhinitis symptoms, or asthma attacks, when they are in environments containing large amounts of HDM. Regarding the involvement of delayed-type hypersensitivity reactions in AD, if a patient experiences periods in which their skin symptoms improve or worsen due to changes in their living environment, e.g., due to moving house, travelling, or hospitalization, mites should be considered to be a potential aggravating factor, and the anti-mite measures described below are recommended [1].

Measures that can reduce HDM levels include the use of wood flooring, floor cleaning, vacuum cleaning bedclothes, drying bedclothes in the sun, and the removal of sofas made of cloth and stuffed toys $[1,2,14]$. While AD lesions were improved by HDM avoidance based on such measures [27,28], reductions in HDM levels had no effect on skin symptoms [29]. The effects of HDM allergen immunotherapy on $\mathrm{AD}$ lesions have been investigated by several groups [30,31]. Ridolo et al. reported that the treatment of $\mathrm{AD}$ with the causative aeroallergen can be used as an add-on therapy in selected patients who are non-responsive to conventional therapy [30].

\subsection{Animal Dander}

In most modern cities, cats and dogs are often present in houses, and some individuals become allergic to proteins found in cat or dog dander. Cats are the second most common source of indoor environmental allergens after HDM. Cat allergens are found at high levels $\left(20 \mathrm{ng} / \mathrm{m}^{3}\right)$ [32]. Ten cat allergens have been identified. The major allergen responsible for symptoms is Fel $\mathrm{d} 1$, a secretoglobin [33].

Čelakovská et al. reported that persistent AD lesions occurred more often in patients that had become sensitized to animal dander or HDM [34]. In addition, IgE sensitization to animal dander or HDM might increase the risk of patients developing asthma or rhinitis [34]. In patients with cat allergies, allergen immunotherapy has been performed with cat dander extract, which was effective at treating cat allergy symptoms, especially respiratory symptoms [35]. In addition, weaker skin test reactions to the cat extract were seen in the treated group than in the placebo group [35].

\subsection{Pollen}

Pollen grains, which represent a small fraction of the viable biological particles present in the air, are important aeroallergens in the outdoor environment. Airborne pollen can exacerbate AD lesions [36-38]. In a previous study, pronounced eczema flare-ups occurred on exposed rather than covered areas of skin. Epicutaneous patch testing with pollen allergen extract induced eczematous lesions in patients with $\mathrm{AD}[36,37]$. In grass pollen-exposed subjects, the serum levels of chemokine (C-C motif) ligand 17 (CCL17), CCL22, and IL-4 were significantly increased [30]. The preventative 
measures that can be used against pollen allergies include brushing pollen off clothes, washing your face when arriving home, wearing glasses and masks, and using air conditioning with pollen filters (Table 3) $[1,2,14]$.

Table 3. Evaluation and management of aeroallergens.

\begin{tabular}{clll}
\hline Allergen & \multicolumn{1}{c}{ Evaluation } & \multicolumn{1}{c}{ Management } & References \\
\hline \multirow{5}{*}{ HDM } & $\begin{array}{l}\text { Serum-specific IgE antibody levels } \\
\text { Skin prick testing and patch testing } \\
\text { Evaluating changes in skin } \\
\text { symptoms caused by environmental } \\
\text { changes (e.g., trips, hospitalization, } \\
\text { or moving house) }\end{array}$ & $\begin{array}{l}\text { Ventilation } \\
\text { Cleaning room } \\
\text { Cleaning bedclothes with a vacuum } \\
\text { cleaner, drying them in the sun, and } \\
\text { washing sheets } \\
\text { Encasing mattresses and bedding to } \\
\text { protect patients from mites }\end{array}$ & {$[1,2,14]$} \\
\hline \multirow{5}{*}{ Animal } \\
dander & $\begin{array}{l}\text { Serum-specific IgE antibody levels } \\
\text { Asking the patient about experiences } \\
\text { involving the worsening of skin } \\
\text { symptoms due to contact with } \\
\text { animals }\end{array}$ & $\begin{array}{l}\text { Giving up pets } \\
\text { Washing pets } \\
\text { Prohibiting pets in the bedroom }\end{array}$ & {$[1,2,14]$} \\
\hline \multirow{5}{*}{ Pollen } & $\begin{array}{l}\text { Serum-specific IgE antibody levels } \\
\text { Skin prick testing and patch testing } \\
\text { Asking the patient about experiences } \\
\text { involving the worsening of skin } \\
\text { symptoms on exposed areas during } \\
\text { a period of pollen scattering }\end{array}$ & $\begin{array}{l}\text { Brushing pollen off clothes and washing } \\
\text { face when arriving home }\end{array}$ & Using protective glasses and masks \\
\hline
\end{tabular}

\section{Food}

\subsection{Blood and Skin Tests}

Food allergens might contribute to the pathogenetic mechanisms of $\mathrm{AD}$, especially during infancy. Serum-specific IgE levels and skin prick test results exhibit high negative predictive values (95\%) and low specificity and positive predictive values (40-60\%) for diagnosing food hypersensitivity [14,39-41]. These findings indicate that negative test results are helpful for ruling out food allergies; however, positive results only signify sensitization and need to be assessed in combination with clinical findings. Therefore, the effects of food allergens should be evaluated based on the results of oral food challenges, which should be performed after causative food elimination in addition to obtaining a detailed medical history and evaluating the patient's serum-specific IgE antibody levels and skin test results $[1,2,14]$.

\subsection{Allergen-Free Diet for Pregnant/Lactating Women}

A systematic review of randomized controlled studies that examined the use of allergen-free diets in pregnant/lactating women has been reported [42]. Dietary restrictions involving allergen elimination in pregnant and lactating women did not prevent the onset of AD in infants. Therefore, dietary restrictions in pregnant and lactating women are not needed to prevent the onset of $A D$ in their children [1].

\subsection{Percutaneous Sensitization in Food Allergy}

Lack et al. performed an epidemiological survey of peanut allergies and detected a significant relationship between peanut allergies and the application of skincare preparations containing peanut oil in children [43]. Based on these findings, the dual-allergen exposure hypothesis, which suggests that oral allergen intake induces immunotolerance, whereas allergen exposure via skin with decreased barrier function induces sensitization, has been proposed [44]. Since the proposal of this hypothesis, allergies caused by percutaneous sensitization, in which sensitization is established by the skin coming into contact with foods, has attracted attention as a mechanism that might be responsible for food allergies. 


\section{Microbial Organisms}

\subsection{Staphylococcus Aureus}

Staphylococcus aureus is frequently detected in AD lesions. Kong et al. reported that the frequency of Staphylococcus sequences, particularly S. aureus, increased during disease flare-ups and was correlated with the severity of skin symptoms in children with AD [45]. In addition, Simpson et al. demonstrated that $\mathrm{AD}$ patients that had been colonized with $S$. aureus had higher levels of type-2 biomarkers (higher blood eosinophil counts and serum levels of total IgE, CCL17, and periostin) and exhibited greater allergen sensitization than both non-colonized AD patients and non-atopic, non-colonized control individuals [46]. Huang et al. investigated the effects of suppressing S. aureus growth with sodium hypochlorite (bleach) baths [47]. The AD patients that received bleach baths displayed significantly greater reductions in disease severity compared with the control subjects.

\subsection{Malassezia Furfur}

The characteristic distribution of AD skin lesions, which often affect the head and neck, implies that an association exists between the exacerbation of $\mathrm{AD}$ and cutaneous microflora, such as Malassezia furfur. Reactivity to Malassezia allergens, which was measured based on serum-specific IgE levels, positive skin prick tests, and positive patch tests, was found to be increased in AD patients with head and neck dermatitis [48-50]. It has been reported that oral [51] and topical antifungal drugs [52] are effective against AD. Taken together with the findings of previous studies into S. aureus and M. furfur, further research is required to fully understand the relationship between the microbial organisms found on the skin and the clinical symptoms of $\mathrm{AD}[1]$.

\section{Contact Allergens}

\subsection{Contact Allergy}

Allergic contact dermatitis is a delayed-type hypersensitivity reaction to small environmental chemicals, i.e., haptens or prehaptens, that come into contact with the skin. Contact allergies can cause refractory eczematous lesions in patients with $\mathrm{AD}$. In particular, if an $\mathrm{AD}$ patient displays an atypical distribution of eczematous lesions, they might be suffering from a contact allergy. According to previous studies, the frequency of contact allergies in $\mathrm{AD}$ patients ranges from $26 \%$ to $54 \%$ [53]. The most common contact allergens are metals, topical drugs, fragrance, and rubber accelerators [53-55] (Table 4). In a previous study, the avoidance of products containing allergenic substances markedly or partially improved eczematous lesions in two-thirds of AD patients that exhibited positive patch test reactions [53]. With regard to nickel and cosmetics, females become sensitized to them more often than males, probably because of their greater use of cosmetics and jewelry, especially among females with pierced ears.

\subsection{Intrinsic $A D$}

$\mathrm{AD}$ can be categorized into the IgE-high, extrinsic type and the IgE-normal, intrinsic type [56]. Extrinsic AD is the classical type, which displays a high prevalence and is associated with elevated IgE levels and skin barrier dysfunction due to decreased filaggrin expression. On the other hand, the incidence of intrinsic $\mathrm{AD}$, which predominantly affects females, is approximately $20 \%$. It has been shown that the percentage of interferon- $\gamma$-producing Th1 cells in the peripheral blood is significantly higher in intrinsic $\mathrm{AD}$ patients than in extrinsic AD patients [57]. Interestingly, patients with intrinsic $\mathrm{AD}$ displayed a higher proportion of positive patch test reactions to metals than those with extrinsic $\mathrm{AD}$, and a metal-free diet partially ameliorated skin symptoms in patients with intrinsic $\mathrm{AD}$, but not those with extrinsic AD [53,58]. Furthermore, Yamaguchi et al. reported that the concentration of nickel in sweat was higher in intrinsic AD patients than in extrinsic AD patients and was inversely 
correlated with serum IgE levels [58]. These findings suggest that metal allergies are a potential cause of intrinsic AD.

Table 4. Representative contact allergens in AD patients.

\begin{tabular}{ccc}
\hline Contact Allergens & Details of Contents & References \\
\hline Metals & $\begin{array}{c}\text { Nickel sulfate } \\
\text { Cobalt chloride } \\
\text { Potassium dichromate }\end{array}$ & {$[53-55]$} \\
\hline Fragrances & $\begin{array}{c}\text { Fragrance mix } \\
\text { Myroxylon }\end{array}$ & {$[53-55]$} \\
\hline Preservae (Balsam of Peru) & $\begin{array}{c}\text { Paraben mix } \\
\text { Thiomersal }\end{array}$ & {$[53,54]$} \\
\hline Rubber accelerators & $\begin{array}{c}\text { Mercapto mix } \\
\text { Thiuram mix } \\
\text { Dithiocarbamate mix }\end{array}$ & {$[53,54]$} \\
\hline Topical drugs & $\begin{array}{c}\text { Steroids } \\
\text { Antibiotics } \\
\text { Moisturizer } \\
\text { Eye drops }\end{array}$ & {$[53-55]$} \\
\hline Cosmetics & Lanolin & {$[53]$} \\
\hline Other chemicals & {$[53,55]$} \\
\hline
\end{tabular}

\section{Sweating}

\subsection{The Function and Composition of Sweat}

Sweat includes natural moisturizing factors (e.g., lactate, urea, and electrolytes, free amino acids, and pyrrolidone carboxylic acid), antimicrobial peptides (e.g., dermcidin, $\beta$-defensins, and cathelicidin), IgA, sodium bicarbonate, pyruvic acid, proteases, and protease inhibitors, and contributes to skin homeostasis, including temperature regulation, skin moisture regulation, and immune functions $[59,60]$. Several previous studies have reported that the composition of sweat was changed in patients with AD [61-63]. Liebke et al. found that the sodium concentration of sweat was significantly higher in children with AD than in healthy children [61]. Moreover, Sugawara et al. showed that patients with AD had significantly reduced levels of sodium, potassium, lactate, urea, and pyrrolidone carboxylic acid in their sweat than healthy controls [62]. These findings suggest that impaired sweating might reduce the levels of natural moisturizing factors and cause dry skin in patients with AD. It is considered that patients with $\mathrm{AD}$ are at higher risk of skin infections and S. aureus colonization. Rieg et al. found that patients with AD displayed significantly lower levels of dermcidin-derived antimicrobial peptides in their sweat than healthy controls [63]. Furthermore, the skin bacterial count after physical exercise-induced sweating was lower in the AD patients than in the healthy subjects [63]. Imayama et al. demonstrated that $\mathrm{AD}$ patients had lower secretory IgA levels in their sweat than healthy controls [64]. These findings suggest that decreased levels of antimicrobial peptides and $\operatorname{IgA}$ in sweat might lead to increased susceptibility to skin infections in patients with AD.

\subsection{Decreased Sweating in AD Patients}

Patients with AD often sweat significantly less than healthy individuals [65-67]. Several possible mechanisms have been suggested to be responsible for the decreased sweating seen in patients with $\mathrm{AD}[59,60]$. It has previously been reported that horny plugs or mucopolysaccharides were seen in the openings of the sweat ducts in conditions involving sweat retention $[68,69]$. With regard to sweat-gland functions, acetylcholine-induced sweating responses were reduced in AD patients compared with those seen in healthy controls, and histamine suppressed acetylcholine-induced sweating via H1 
receptor-mediated signaling [70,71]. Furthermore, sweat leakage into the surrounding tissues was observed in patients with AD. The leakage of sweat, as demonstrated by sweat gland-specific dermcidin expression in the dermis around the sweat ducts and glands, was specifically detected in the skin of AD patients [72]. Interestingly, the expression of claudin-3, which acts as a component of the tight junctions between the luminal cells throughout the sweat gland, was significantly reduced in patients with AD compared with that observed in healthy individuals [71]. The reductions in sweating induced via these mechanisms might cause skin dryness and increase patients' susceptibility to infection, resulting in the exacerbation of the symptoms of AD.

\subsection{Sweat Allergies}

While sweat is important for maintaining homeostasis, it is likely to induce pruritus in patients with AD. Hide et al. reported that intradermal tests with autologous sweat induced positive reactions in many patients with $\mathrm{AD}$ [73]. In addition, it has been reported that patients with AD exhibited positive reactions to sweat antigens in a histamine release test [73]. Interestingly, Hiragun et al. found that MGL_1304, a fungal protein derived from Malassezia globosa, is a major antigen in human sweat, and recombinant MGL_1304 induced histamine release from basophils in most AD patients [74]. Patients with AD might develop immediate-type hypersensitivity reactions to sweat antigens, leading to exacerbated itching and irritation in response to sweating. These findings suggest that mast cells might react to sweat that leaks from weak sweat ducts and glands in patients with AD.

\subsection{Measures for Sweating}

It is not necessary to avoid sweating because sweating is important for skin homeostasis. However, leaving excess sweat on the skin surface can induce itching in patients with AD. Several studies have shown that taking a shower after sweating is effective at relieving symptoms $[75,76]$. Therefore, if excess sweat remains on the skin surface, it can be washed away or wiped off [1].

\section{Scratching Behavior}

\subsection{Scratching-Induced Aggravation of AD Lesions}

Patients with AD often scratch their skin, resulting in further skin damage, which can lead to the exacerbation of eczematous lesions. It has been hypothesized that IL-33, IL-25, and TSLP, which are released from epidermal keratinocytes, act as endogenous "danger signals" or "alarmins" that alert the immune system to tissue damage [77]. It has been shown that the serum levels of IL-33 were higher in AD patients than in healthy individuals [78]. In addition, the patients' serum IL-33 levels were correlated with their excoriation scores [78]. These findings suggest that tissue injuries caused by scratching of the skin might result in increased release of keratinocyte-derived cytokines, including IL-33, from damaged cells in patients with AD. Moreover, several previous studies have suggested that endogenous molecules that are released from tissues or cells by skin damage, including scratching, stimulate immune reactions in allergic dermatitis [79-81]. Therefore, scratching contributes to the exacerbation of eczematous lesions in AD.

\subsection{Factors Influencing Scratching Behavior}

Scratching can be caused by various itching-related and non-itching-related factors (Table 5). Itching signals are transmitted from the periphery to the brain via the dorsal horn by primary sensory neurons and spinothalamic tract neurons, and itching is induced by various mediators [77,82,83]. At the periphery, histamine acts as a pruritogen. Several type-2 cytokines, such as IL-4, IL-13, and IL-31, also directly activate sensory neurons [77,84-87]. Targeting the IL-31 pathway has been shown to be effective in patients with AD [84]. IL-4 and IL-13 are cytokines that are central to the pathogenesis of atopic disease and are primarily produced by Th2 cells [77]. Dupilumab is a human monoclonal antibody that is directed against the $\alpha$-subunit of the IL-4 receptor. It blocks signaling from both IL-4 
and IL-13 [85]. The administration of dupilumab resulted in significant improvements in inflammation and pruritus in AD patients [86]. Moreover, the epithelium-derived cytokine TSLP, which is deeply involved in the development of inflammatory responses in AD [77], acts directly on a subset of primary sensory neurons and induces itching [87].

Table 5. Major factors influencing scratching in AD.

\begin{tabular}{|c|c|c|}
\hline Factors & Details of Contents & References \\
\hline \multirow{6}{*}{ Inflammatory mediators } & Amines (histamine, serotonin) & {$[13,88]$} \\
\hline & Cytokines (IL-4, IL-13, IL-31, IL-33, and TSLP) & {$[77,82,83]$} \\
\hline & $\begin{array}{l}\text { Proteases (kallikreins, tryptase, } \\
\text { endogenous/exogenous proteases) }\end{array}$ & {$[89,90]$} \\
\hline & Neuropeptides (substance P) & {$[91,92]$} \\
\hline & $\begin{array}{l}\text { Neurotrophic factors (nerve growth factor, } \\
\text { artemin) }\end{array}$ & {$[82,93]$} \\
\hline & Neurotransmitters (acetylcholine) & [94] \\
\hline \multirow[t]{3}{*}{ Environmental factors } & Temperature, humidity, dry environments & [83] \\
\hline & Psychological stress & {$[1,83]$} \\
\hline & Habitual scratching & [1] \\
\hline
\end{tabular}

In addition to these mediators, proteases (e.g., kallikreins, tryptase, endogenous/exogenous proteases) [89,90], neuropeptides (e.g., substance P) [91,92], and neurotrophic factors (nerve growth factor (NGF), artemin) $[82,83,93]$ are considered to contribute to pruritus. Moreover, it has been reported that abnormal elongation of the sensory nerves into the epidermis occurs in the skin of AD patients [82]. In a mouse model of dry skin-induced itching, the expression of NGF was found to be elevated in the skin, and the number of intradermal nerve fibers increased [95]. On the other hand, semaphorins are a class of secreted membrane proteins, which function as axonal growth cone guidance molecules [82]. Semaphorin 3A is the first member of the semaphorin family that has been shown to cause growth cone collapse in neurons [96]. Semaphorin 3A regulates NGF-induced sprouting of sensory afferents in the spinal cord [97]. The abnormal elongation of the sensory nerves seen in AD is considered to be caused by an imbalance in the levels of nerve elongation factors, such as NGF, and nerve-repulsion factors, such as semaphorin 3A [82]. Such abnormal extension of the sensory nerves into the epidermis might lead to mechanical itching-induced dysesthesia, in which abnormal sensory states are induced by light cutaneous stimuli (alloknesis) [77,83]. In addition, patients with $\mathrm{AD}$ can experience strong itching in response to normal itch-evoking stimuli (hyperkinesis) $[77,83]$. Non-itching sensations, such as heat and pain, can also be experienced as itching by patients with $\mathrm{AD}[83]$.

The micro-opioid (beta-endorphin/micro-opioid receptor) and kappa-opioid (dynorphin A (DynA)/kappa-opioid receptor) systems are involved in the regulation of pruritus in the central nervous system. It has been reported that the micro-opioid and kappa-opioid systems are present in the human epidermis [98], suggesting that these systems might be responsible for peripheral pruritus. Kumagai et al. suggested that the micro-opioid system is itch-inducible, while the kappa-opioid system is itch-suppressive [99]. Interestingly, Tominaga et al. reported that the kappa-opioid system was downregulated in the epidermises of AD patients [100], indicating that patients with AD might experience itching due to the downregulation of the itch-suppressive system.

Patients with AD often scratch their skin in response to factors that are not related to itching. With regard to psychological aspects, it is known that the itching symptoms of AD patients can be worsened by stress and can be improved by stress management and behavioral modification [1]. Moreover, a vicious cycle of itching, scratching, and damaged skin might lead to scratching mainly out of habit instead of due to itching (habitual scratching). Thus, it is important to consider the possible 
involvement of such non-itching-related factors in addition to suppressing inflammation and pruritus in order to control the scratching behavior of AD patients.

\section{Other Factors}

\subsection{Psychological Stressors}

Emotional stress can increase not only itching but also the inflammation via the release of inflammatory mediators in AD patients [101,102]. The patients with AD had higher anxiety levels than healthy individuals, and those with a stronger trait anxiety than state anxiety showed elevated serum IgE levels and Th2 shifting [101]. Moreover, psychological variables affect serum levels of interferon- $\gamma$ and IL-4 more in the patients with AD than healthy individuals [102]. These findings suggest that psychological stressors might affect the immunological reactions in the patients with AD.

\subsection{Circadian Rhythms}

Clinical symptoms in patients with allergic diseases including AD often depend on diurnal variations [103]. An intrinsic daily physiological rhythm called circadian rhythm is thought to affect the immune system. Several experimental studies have demonstrated that mutation in the circadian clock genes greatly affects immune responses [104-106]. Immune tolerance development is closely associated with the onset of immunological disorders. It has been shown that exposure to constant light impairs circadian rhythms, leading to the disturbance of tolerance induction [107]. Therefore, constant light environments such as lighting conditions at home in our night-active modern society may affect the development of $\mathrm{AD}$.

\section{Conclusions}

Various aggravating factors, including both allergic and non-allergic factors, have been suggested to influence the course of AD. To identify factors that are specific to individual patients, it is important to consider whether the degree of eczematous lesions is affected by environmental changes, oral food challenges, or the avoidance of contact with suspected causative substances. In addition, we need to establish treatment strategies that take patients' lifestyles into account. Furthermore, it is not necessary for AD patients to avoid sweating because it is important for skin homeostasis. However, leaving excess sweat on the skin can induce skin symptoms; therefore, sweat should be washed away or wiped off. Moreover, scratching leads to further skin damage, resulting in the exacerbation of eczematous lesions. It is important to consider clinical factors that might influencing scratching behavior (e.g., inflammation, stress, and habitual scratching). Future studies will contribute to the elucidation of the pathogenetic mechanism of $\mathrm{AD}$, leading to improvements in the management of complicating factors.

Author Contributions: R.T.-M. wrote the first draft. N.K. reviewed the draft. R.T.-M. finalized the article, and both authors approved the submission of the article. All authors have read and agreed to the published version of the manuscript.

Funding: This research received no external funding.

Conflicts of Interest: R.T.-M. has no conflict of interest to declare. N.K. has received honoraria and research grants (to the Department of Dermatology, Kyoto Prefectural University of Medicine) from AbbVie, Lilly, LEO Pharma, Maruho, Mitsubishi Tanabe, Kyowa Kirin, Taiho, Regeneron, and Sanofi.

\section{References}

1. Katoh, N.; Ohya, Y.; Ikeda, M.; Ebihara, T.; Katayama, I.; Saeki, H.; Shimojo, N.; Tanaka, A.; Nakahara, T.; Nagao, M.; et al. Clinical practice guidelines for the management of atopic dermatitis 2018. J. Dermatol. 2019, 46, 1053-1101. [CrossRef] [PubMed]

2. Ring, J.; Alomar, A.; Bieber, T.; Deleuran, M.; Fink-Wagner, A.; Gelmetti, C.; Gieler, U.; Lipozencic, J.; Luger, T.; Oranje, A.P.; et al. Guidelines for treatment of atopic eczema (atopic dermatitis) Part I. J. Eur. Acad. Dermatol. Venereol. 2012, 26, 1045-1060. [CrossRef] [PubMed] 
3. Eichenfield, L.F.; Tom, W.L.; Chamlin, S.L.; Feldman, S.R.; Hanifin, J.M.; Simpson, E.L.; Berger, T.G.; Bergman, J.N.; Cohen, D.E.; Cooper, K.D.; et al. Guidelines of care for the management of atopic dermatitis: Section 1 diagnosis and assessment of atopic dermatitis. J. Am. Acad. Dermatol. 2014, 70, 338-351. [CrossRef] [PubMed]

4. Williams, H.C. Atopic dermatitis. In The Epidemiology, Causes and Prevention of Atopic Eczema; Williams, H.C., Ed.; Cambridge University Press: Cambridge, UK, 2000.

5. Elias, P.M. Stratum corneum defensive functions: An integrated view. J. Gen. Intern Med. 2005, 125, $183-200$. [CrossRef] [PubMed]

6. Melnik, B.; Hollmann, J.; Plewig, G. Decreased stratum corneum ceramides in atopic individuals-a pathobiochemical factor in xerosis? Br. J. Dermatol. 1988, 119, 547-549. [CrossRef] [PubMed]

7. Cabanillas, B.; Novak, N. Atopic dermatitis and filaggrin. Curr. Opin. Immunol. 2016, 42, 1-8. [CrossRef]

8. Kono, M.; Nomura, T.; Ohguchi, Y.; Mizuno, O.; Suzuki, S.; Tsujiuchi, H.; Hamajima, N.; McLean, W.H.; Shimizu, H.; Akiyama, M. Comprehensive screening for a complete set of Japanese-population-specific filaggrin gene mutations. Allergy 2014, 69, 537-540. [CrossRef]

9. Eichenfield, L.F.; Tom, W.L.; Berger, T.G.; Krol, A.; Paller, A.S.; Schwarzenberger, K.; Bergman, J.N.; Chamlin, S.L.; Cohen, D.E.; Cooper, K.D.; et al. Guidelines of care for the management of atopic dermatitis: Section Management and treatment of atopic dermatitis with topical therapies. J. Am. Acad. Dermatol. 2014, 71, 116-132. [CrossRef]

10. Sidbury, R.; Davis, D.M.; Cohen, D.E.; Cordoro, K.M.; Berger, T.G.; Bergman, J.N.; Chamlin, S.L.; Cooper, K.D.; Feldman, S.R.; Hanifin, J.M.; et al. Guidelines of care for the management of atopic dermatitis: Section 3. Management and treatment with phototherapy and systemic agents. J. Am. Acad. Dermatol. 2014, 71, 327-349. [CrossRef]

11. Elias, P.M.; Hatano, Y.; Williams, M.L. Basis for the barrier abnormality in atopic dermatitis: Outside-inside-outside pathogenic mechanisms. J. Allergy Clin. Immunol. 2008, 121, 1337-13343. [CrossRef]

12. Diepgen, T.L.; Stäbler, A.; Hornstein, O.P. Textile intolerance in atopic eczema -a controlled clinical study. Z. Hautkr. 1990, 65, 907-910. [PubMed]

13. Wahlgren, C.F.; Hägermark, O.; Bergström, R. Patients' perception of itch induced by histamine, compound 48/80 and wool fibres in atopic dermatitis. Acta. Derm. Venereol. 1991, 71, 488-494. [PubMed]

14. Sidbury, R.; Tom, W.L.; Bergman, J.N.; Cooper, K.D.; Silverman, R.A.; Berger, T.G.; Chamlin, S.L.; Cohen, D.E.; Cordoro, K.M.; Davis, D.M. Guidelines of care for the management of atopic dermatitis: Section 4. J. Am. Acad. Dermatol. 2014, 71, 1218-1233. [CrossRef] [PubMed]

15. Thomas, W.R. Hierarchy and molecular properties of house dust mite allergens. Allergol. Int. 2015, 64, 304-311. [CrossRef] [PubMed]

16. Allergen Nomenclature. WHO/IUIS Allergen Nomenclature Sub-Committee. Available online: www. allergen.org/ (accessed on 15 August 2019).

17. Tovey, E.R.; Willenborg, C.M.; Crisafulli, D.A.; Rimmer, J.; Marks, G.B. Marks most personal exposure to house dust mite aeroallergen occurs during the day. PLoS ONE 2013, 8, e69900. [CrossRef] [PubMed]

18. Darsow, U.; Vieluf, D.; Ring, J. Evaluating the relevance of aeroallergen sensitization in atopic eczema with the atopy patch test: A randomized, double-blind multicenter study. Atopy Patch Test Study Group. J. Am. Acad. Dermatol. 1999, 40, 187-193. [CrossRef]

19. Darsow, U.; Laifaoui, J.; Kerschenlohr, K.; Wollenberg, A.; Przybilla, B.; Wüthrich, B.; Borelli, S., Jr.; Giusti, F.; Seidenari, S.; Drzimalla, K.; et al. The prevalence of positive reactions in the atopy patch test with aeroallergens and food allergens in subjects with atopic eczema: A European multicenter study. Allergy 2004, 59, 1318-1325. [CrossRef]

20. Katoh, N.; Hirano, S.; Suehiro, M.; Masuda, K.; Kishimoto, S. The characteristics of patients with atopic dermatitis demonstrating a positive reaction in a scratch test after 48 hours against house dust mite antigen. J. Dermatol. 2004, 31, 720-726. [CrossRef]

21. Bruijnzeel-Koomen, C.; van Wicker, D.; Toonstra, J.; Bruijnzeel, P. The presence of IgE molecules on epidermal Langerhans cells from patients with atopic dermatitis. Arch. Dermatol. Res. 1986, 278, 199-205. [CrossRef]

22. Mudde, G.C.; van Reijsen, F.C.; Boland, G.J.; de Gast, G.C.; Bruijnzeel, P.L.; Bruijnzeel-Koomen, C.A. Allergen presentation by epidermal Langerhans' cells from patients with atopic dermatitis is mediated by IgE. Immunology 1990, 69, 335-341. 
23. Bieber, T.; de la Salle, H.; Wollenberg, A. Human epidermal Langerhans cells express the high affinity receptor for immunoglobulin E (FceRI). J. Exp. Med. 1992, 175, 1285-1290. [CrossRef] [PubMed]

24. Wang, B.; Rieger, A.; Kilgus, O. Epidermal Langerhans cells from normal human skin bind monomeric IgE via FceRI. J. Exp. Med. 1992, 175, 1353-1365. [CrossRef] [PubMed]

25. Jürgens, M.L.; Wollenberg, A.; Hanau, D.; de la Salle, H.; Bieber, T. Activation of human epidermal Langerhans cells by engagement of the high affinity receptor for IgE, FceRI. J. Immunol. 1995, 155, 5184-5189. [PubMed]

26. Darsow, U.; Vieluf, D.; Ring, J. The atopy patch test: An increased rate of reactivity in patients who have an air-exposed pattern of atopic eczema. Br. J. Dermatol. 1996, 135, 182-186. [CrossRef]

27. Ricci, G.; Patrizi, A.; Specchia, F.; Menna, L.; Bottau, P.; D'Angelo, V.; Masi, M. Effect of house dust mite avoidance measures in children with atopic dermatitis. Br. J. Dermatol. 2000, 143, 379-384. [CrossRef]

28. Oosting, A.J.; de Bruin-Weller, M.S.; Terreehorst, I.; Tempels-Pavlica, Z.; Aalberse, R.C.; de Monchy, J.G.; van Wijk, R.G.; Bruijnzeel-Koomen, C.A. Effect of mattress encasings on atopic dermatitis outcome measures in a double-blind, placebo-controlled study: The Dutch mite avoidance study. J. Allergy. Clin. Immunol. 2002, 110, 500-506. [CrossRef]

29. Gutgesell, C.; Heise, S.; Seubert, S.; Seubert, A.; Domhof, S.; Brunner, E.; Neumann, C. Double-blind placebo-controlled house dust mite control measures in adult patients with atopic dermatitis. Br. J. Dermatol. 2001, 145, 70-74. [CrossRef]

30. Ridolo, E.; Martignago, I.; Galeazzo Riario-Sforza, G.; Incorvaia, C. Allergen immunotherapy in atopic dermatitis. Expert Rev. Clin. Immunol. 2018, 14, 61-68. [CrossRef]

31. Bussmann, C.; Bo“ ckenhoff, A.; Henke, H.; Werfel, T.; Novak, N. Does allergen-specific immunotherapy represent a therapeutic option for patients with atopic dermatitis? J. Allergy Clin. Immunol. 2006, 118, 1292-1298. [CrossRef]

32. Thomas, W.R. Innate affairs of allergens. Clin. Exp. Allergy 2013, 43, 152-163. [CrossRef]

33. Bonnet, B.; Messaoudi, K.; Jacomet, F.; Michaud, E.; Fauquert, J.L.; Caillaud, D.; Evrard, B. An update on molecular cat allergens: Fel d 1 and what else? Chapter 1: Fel d 1, the major cat allergen. Allergy Asthma. Clin. Immunol. 2018, 14, 14. [CrossRef] [PubMed]

34. Čelakovská, J.; Ettlerová, K.; Ettler, K.; Vaněčková, J.; Bukač, J. Sensitization to aeroallergens in atopic dermatitis patients: Association with concomitant allergic diseases. J. Eur. Acad. Dermatol. Venereol. 2015, 29, 1500-1505. [CrossRef] [PubMed]

35. Alvarez-Cuesta, E.; Berges-Gimeno, P.; González-Mancebo, E.; Mancebo, E.G.; Fernández-Caldas, E.; Cuesta-Herranz, J.; Casanovas, M. Sublingual immunotherapy with a standardized cat dander extract: Evaluation of efficacy in a double blind placebo controlled study. Allergy 2007, 62, 810-817. [CrossRef] [PubMed]

36. Yokozeki, H.; Takayama, K.; Katayama, I.; Nishioka, K. Japanese cedar pollen as an exacerbation factor in atopic dermatitis: Results of atopy patch testing and histological examination. Acta. Derm. Venereol. 2006, 86, 148-151.

37. Darsow, U.; Behrendt, H.; Ring, J. Gramineae pollen as trigger factors of atopic eczema: Evaluation of diagnostic measures using the atopy patch test. Br. J. Dermatol. 1997, 137, 201-207. [CrossRef]

38. Werfel, T.; Heratizadeh, A.; Niebuhr, M.; Kapp, A.; Roesner, L.M.; Karch, A.; Erpenbeck, V.J.; Lösche, C.; Jung, T.; Krug, N. Exacerbation of atopic dermatitis on grass pollen exposure in an environmental challenge chamber. J. Allergy Clin. Immunol. 2015, 136, 96-103. [CrossRef]

39. Bock, S.A.; Lee, W.Y.; Remigio, L.; Holst, A.; May, C.D. Appraisal of skin tests with food extracts for diagnosis of food hypersensitivity. Clin. Allergy 1978, 8, 559-564. [CrossRef]

40. Sampson, H.A.; Albergo, R. Comparison of results of skin tests, RAST, and double-blind, placebo-controlled food challenges in children with atopic dermatitis. J. Allergy Clin. Immunol. 1984, 74, 26-33. [CrossRef]

41. Lemon-Mule, H.; Nowak-Wegrzyn, A.; Berin, C.; Knight, A.K. Pathophysiology of food-induced anaphylaxis. Curr. Allergy Asthma. Rep. 2008, 8, 201-208. [CrossRef]

42. Kramer, M.S.; Kakuma, R. Maternal dietary antigen avoidance during pregnancy or lactation, or both, for preventing or treating atopic disease in the child. Cochrane Database Syst. Rev. 2012, 9, CD000133. [CrossRef] [PubMed]

43. Lack, G.; Fox, D.; Northstone, K.; Golding, J. Avon Longitudinal Study of Parents and Children Study Team. Factors associated with the development of peanut allergy in childfood. N Engl. J. Med. 2003, 348, 977-985. [CrossRef] [PubMed] 
44. Lack, G. Epidemiologic risks for food allergy. J. Allergy Clin. Immunol. 2008, 129, 1187-1197. [CrossRef] [PubMed]

45. Kong, H.H.; Oh, J.; Deming, C.; Conlan, S.; Grice, E.A.; Beatson, M.A.; Nomicos, E.; Polley, E.C.; Komarow, H.D.; NISC Comparative Sequence Program; et al. Temporal shifts in the skin microbiome associated with disease flares and treatment in children with atopic dermatitis. Genome. Res. 2012, 22, 850-859. [CrossRef] [PubMed]

46. Simpson, E.L.; Villarreal, M.; Jepson, B.; Rafaels, N.; David, G.; Hanifin, J.; Taylor, P.; Boguniewicz, M.; Yoshida, T.; De Benedetto, A.; et al. Patients with atopic dermatitis colonized with Staphylococcus aureus have a distinct phenotype and endotype. J. Investig. Dermatol. 2018, 138, 2224-2233. [CrossRef] [PubMed]

47. Huang, J.T.; Abrams, M.; Tlougan, B.; Rademaker, A.; Paller, A.S. Treatment of staphylococcus aureus colonization in atopic dermatitis decreases disease severity. Pediatrics 2009, 123, e808-e814. [CrossRef] [PubMed]

48. Johansson, C.; Sandström, M.H.; Bartosik, J.; Särnhult, T.; Christiansen, J.; Zargari, A.; Bäck, O.; Wahlgren, C.F.; Faergemann, J.; Scheynius, A.; et al. Atopy patch test reactions to Malassezia allergens differentiate subgroups of atopic dermatitis patients. Br. J. Dermatol. 2003, 148, 479-488. [CrossRef]

49. Kim, T.Y.; Jang, I.G.; Park, Y.M.; Kim, H.O.; Kim, C.W. Head and neck dermatitis: The role of Malassezia furfur, topical steroid use and environmental factors in its causation. Clin. Exp. Dermatol. 1999, 24, 226-231. [CrossRef]

50. Johansson, C.; Eshaghi, H.; Linder, M.T.; Jakobson, E.; Scheynius, A. Positive atopy patch test reaction to Malassezia furfur in atopic dermatitis correlates with a T helper 2-like peripheral blood mononuclear cells response. J. Investig. Dermatol. 2002, 118, 1044-1051. [CrossRef]

51. Takechi, M. Minimum effective dosage in the treatment of chronic atopic dermatitis with itraconazole. J. Int. Med. Res. 2005, 33, 2732-2783. [CrossRef]

52. Mayser, P.; Kupfer, J.; Nemetz, D.; Schäfer, U.; Nilles, M.; Hort, W.; Gieler, U. Treatment of head and neck dermatitis with ciclopiroxolamine cream-results of a double-blind, placebo-controlled study. Skin. Pharmacol. Physiol. 2006, 19, 1531-1558. [CrossRef]

53. Tamagawa-Mineoka, R.; Masuda, K.; Ueda, S.; Nakamura, N.; Hotta, E.; Hattori, J.; Minamiyama, R.; Yamazaki, A.; Katoh, N. Contact sensitivity in patients with recalcitrant atopic dermatitis. J. Dermatol. 2015, 42, 720-722. [CrossRef] [PubMed]

54. Thyssen, J.P.; Johansen, J.D.; Linneberg, A.; Menné, T.; Engkilde, K. The association between contact sensitization and atopic disease by linkage of a clinical database and a nationwide patient registry. Allergy 2012, 67, 1157-1164. [CrossRef] [PubMed]

55. Giordano-Labadie, F.; Rance, F.; Pellegrin, F.; Bazex, J.; Dutau, G.; Schwarze, H.P. Frequency of contact allergy in children with atopic dermatitis: Results of a prospective study of 137 cases. Contact Dermatitis 1999, 40, 192-195. [CrossRef] [PubMed]

56. Tokura, Y. Extrinsic and intrinsic types of atopic dermatitis. J. Dermatol. Sci. 2010, 58, 1-7. [CrossRef] [PubMed]

57. Kabashima-Kubo, R.; Nakamura, M.; Sakabe, J.; Sugita, K.; Hino, R.; Mori, T.; Kobayashi, M.; Bito, T.; Kabashima, K.; Ogasawara, K.; et al. A group of atopic dermatitis without IgE elevation or barrier impairment shows a high Th1 frequency: Possible immunological state of the intrinsic type. J. Dermatol. Sci. 2012, 67, 37-43. [CrossRef] [PubMed]

58. Yamaguchi, H.; Kabashima-Kubo, R.; Bito, T.; Sakabe, J.; Shimauchi, T.; Ito, T.; Hirakawa, S.; Hirasawa, N.; Ogasawara, K.; Tokura, Y. High frequencies of positive nickel/cobalt patch tests and high sweat nickel concentration in patients with intrinsic atopic dermatitis. J. Dermatol. Sci. 2013, 72, 240-245. [CrossRef] [PubMed]

59. Murota, H.; Yamaga, K.; Ono, E.; Katayama, I. Sweat in the pathogenesis of atopic dermatitis. Allergol. Int. 2018, 67, 455-459. [CrossRef]

60. Shelmire, J.B., Jr. Some interrelations between sebum, sweat and the skin surface. J. Investig. Dermatol. 1959, 32, 471-472. [CrossRef]

61. Liebke, C.; Wahn, U.; Niggemann, B. Sweat electrolyte concentrations in children with atopic dermatitis. Lancet 1997, 350, 1678-1679. [CrossRef] 
62. Sugawara, T.; Kikuchi, K.; Tagami, H.; Aiba, S.; Sakai, S. Decreased lactate and potassium levels in natural moisturizing factor from the stratum corneum of mild atopic dermatitis patients are involved with the reduced hydration state. J. Dermatol. Sci. 2012, 66, 154-159. [CrossRef]

63. Rieg, S.; Steffen, H.; Seeber, S.; Humeny, A.; Kalbacher, H.; Dietz, K.; Garbe, C.; Schittek, B. Deficiency of dermcidin-derived antimicrobial peptides in sweat of patients with atopic dermatitis correlates with an impaired innate defense of human skin in vivo. J. Immunol. 2005, 174, 8003-8010. [CrossRef] [PubMed]

64. Imayama, S.; Shimozono, Y.; Hoashi, M.; Yasumoto, S.; Ohta, S.; Yoneyama, K.; Hori, Y. Reduced secretion of IgA to skin surface of patients with atopic dermatitis. J. Allergy Clin. Immunol. 1994, 94, 195-200. [CrossRef] [PubMed]

65. Eishi, K.; Lee, J.B.; Bae, S.J.; Takenaka, M.; Katayama, I. Impaired sweating function in adult atopic dermatitis: Results of the quantitative sudomotor axon reflex test. Br. J. Dermatol. 2002, 147, 683-688. [CrossRef] [PubMed]

66. Kijima, A.; Murota, H.; Matsui, S.; Takahashi, A.; Kimura, A.; Kitaba, S.; Lee, J.B.; Katayama, I. Abnormal axon reflex-mediated sweating correlates with high state of anxiety in atopic dermatitis. Allergol. Int. 2012, 61, 469-473. [CrossRef] [PubMed]

67. Takahashi, A.; Murota, H.; Matsui, S.; Kijima, A.; Kitaba, S.; Lee, J.B.; Katayama, I. Decreased sudomotor function is involved in the formation of atopic eczema in the cubital fossa. Allergol. Int. 2013, 62, 473-478. [CrossRef] [PubMed]

68. Sulzberger, M.B.; Herrmann, F.; Zak, F.G. Studies of sweating; preliminary report with particular emphasis of a sweat retention syndrome. J. Investig. Dermatol. 1947, 9, 221-242. [CrossRef]

69. Papa, C.M.; Kligman, A.M. Mechanisms of eccrine anidrosis. I. High level blockade. J. Investig. Dermatol. 1966, 47, 1-9. [CrossRef]

70. Murota, H.; Matsui, S.; Ono, E.; Kijima, A.; Kikuta, J.; Ishii, M.; Katayama, I. Sweat, the driving force behind normal skin: An emerging perspective on functional biology and regulatory mechanisms. J. Dermatol. Sci. 2015, 77, 3-10. [CrossRef]

71. Matsui, S.; Murota, H.; Takahashi, A.; Yang, L.; Lee, J.B.; Omiya, K.; Ohmi, M.; Kikuta, J.; Ishii, M.; Katayama, I. Dynamic Analysis of Histamine-Mediated Attenuation of Acetylcholine-Induced Sweating via GSK3 $\beta$ Activation. J. Investig. Dermatol. 2014, 134, 326-334. [CrossRef]

72. Shiohara, T.; Doi, T.; Hayakawa, J. Defective sweating responses in atopic dermatitis. Curr. Probl. Dermatol. 2011, 41, 68-79.

73. Hide, M.; Tanaka, T.; Yamamura, Y.; Koro, O.; Yamamoto, S. IgE-mediated hypersensitivity against human sweat antigen in patients with atopic dermatitis. Acta. Derm. Venereol. 2002, 82, 335-340. [CrossRef] [PubMed]

74. Hiragun, T.; Ishii, K.; Hiragun, M.; Suzuki, H.; Kan, T.; Mihara, S.; Yanase, Y.; Bartels, J.; Schröder, J.M.; Hide, M. Fungal protein MGL_1304 in sweat is an allergen for atopic dermatitis patients. J. Allergy Clin. Immunol. 2013, 132, 608-615. [CrossRef]

75. Murota, H.; Takahashi, A.; Nishioka, M.; Matsui, S.; Terao, M.; Kitaba, S.; Katayama, I. Showering reduces atopic dermatitis in elementary school students. Eur. J. Dermatol. 2010, 20, 4104-4111. [CrossRef] [PubMed]

76. Mochizuki, H.; Muramatsu, R.; Tadaki, H.; Mizuno, T.; Arakawa, H.; Morikawa, A. Effects of skin care with shower therapy on children with atopic dermatitis in elementary schools. Pediatr. Dermatol. 2009, 26, 223-225. [CrossRef] [PubMed]

77. Kabashima, K. New concept of the pathogenesis of atopic dermatitis: Interplay among the barrier, allergy, and pruritus as a trinity. J. Dermatol. Sci. 2013, 70, 3-11. [CrossRef] [PubMed]

78. Tamagawa-Mineoka, R.; Okuzawa, Y.; Masuda, K.; Katoh, N. Increased serum levels of interleukin 33 in patients with atopic dermatitis. J. Am. Acad. Dermatol. 2014, 70, 882-888. [CrossRef] [PubMed]

79. Nakamura, N.; Tamagawa-Mineoka, R.; Ueta, M.; Kinoshita, S.; Katoh, N. Toll-like receptor 3 increases allergic and irritant contact dermatitis. J. Investig. Dermatol. 2015, 135, 411-417. [CrossRef]

80. Yoon, J.; Leyva-Castillo, J.M.; Wang, G.; Galand, C.; Oyoshi, M.K.; Kumar, L.; Hoff, S.; He, R.; Chervonsky, A.; Oppenheim, J.J.; et al. IL-23 induced in keratinocytes by endogenous TLR4 ligands polarizes dendritic cells to drive IL-22 responses to skin immunization. J. Exp. Med. 2016, 213, 2147-2166. [CrossRef]

81. Bernard, J.J.; Cowing-Zitron, C.; Nakatsuji, T.; Muehleisen, B.; Muto, J.; Borkowski, A.W.; Martinez, L.; Greidinger, E.L.; Yu, B.D.; Gallo, R.L. Ultraviolet radiation damages self noncoding RNA and is detected by TLR3. Nat. Med. 2012, 18, 1286-1290. [CrossRef] 
82. Tominaga, M.; Takamori, K. Itch and nerve fibers with special reference to atopic dermatitis: Therapeutic implications. J. Dermatol. 2014, 41, 205-212. [CrossRef]

83. Murota, H.; Katayama, I. Exacerbating factors of itch in atopic dermatitis. Allergol. Int. 2017, 66, 8-13. [CrossRef] [PubMed]

84. Meng, J.; Moriyama, M.; Feld, M.; Buddenkotte, J.; Buhl, T.; Szöllösi, A.; Zhang, J.; Miller, P.; Ghetti, A.; Fischer, M.; et al. New mechanism underlying IL-31-induced atopic dermatitis. J. Allergy Clin. Immunol. 2018, 141, 1677-1689. [CrossRef] [PubMed]

85. Gooderham, M.J.; Hong, H.C.; Eshtiaghi, P.; Papp, K.A. Dupilumab: A review of its use in the treatment of atopic dermatitis. J. Am. Acad. Dermatol. 2018, 78, S28-S36. [CrossRef]

86. Uchida, H.; Kamata, M.; Mizukawa, I.; Watanabe, A.; Agematsu, A.; Nagata, M.; Fukaya, S.; Hayashi, K.; Fukuyasu, A.; Tanaka, T.; et al. Real-world effectiveness and safety of dupilumab for the treatment of atopic dermatitis in Japanese patients: A single-centre retrospective study. Br. J. Dermatol. 2019, 181, 1083-1085. [CrossRef] [PubMed]

87. Wilson, S.R.; Thé, L.; Batia, L.M.; Beattie, K.; Katibah, G.E.; McClain, S.P.; Pellegrino, M.; Estandian, D.M.; Bautista, D.M. The epithelial cell-derived atopic dermatitis cytokine TSLP activates neurons to induce itch. Cell 2013, 155, 285-295. [CrossRef]

88. Bautista, D.M.; Wilson, S.R.; Hoon, M.A. Why we scratch an itch: The molecules, cells and circuits of itch. Nat. Neurosci. 2014, 17, 175-182. [CrossRef]

89. Steinhoff, M.; Neisius, U.; Ikoma, A.; Fartasch, M.; Heyer, G.; Skov, P.S.; Luger, T.A.; Schmelz, M. Proteinase-activated receptor-2 mediates itch: A novel pathway for pruritus in human skin. J. Neurosci. 2003, 23, 6176-6180. [CrossRef]

90. Kempkes, C.; Buddenkotte, J.; Cevikbas, F.; Buhl, T.; Steinhoff, M. Role of PAR-2 in Neuroimmune Communication and Itch. In Itch: Mechanisms and Treatment; Carstens, E., Akiyama, T., Eds.; CRC Press/Taylor \& Francis: Boca Raton, FL, USA, 2014.

91. Hon, K.L.; Lam, M.C.; Wong, K.Y.; Leung, T.F.; Ng, P.C. Pathophysiology of nocturnal scratching in childhood atopic dermatitis: The role of brain-derived neurotrophic factor and substance P. Br. J. Dermatol. 2007, 157, 922-925. [CrossRef]

92. Heyer, G.; Hornstein, O.P.; Handwerker, H.O. Reactions to intradermally injected substance P and topically applied mustard oil in atopic dermatitis patients. Acta. Derm. Venereol. 1991, 71, 291-295.

93. Murota, H.; Izumi, M.; Abd El-Latif, M.I.; Nishioka, M.; Terao, M.; Tani, M.; Matsui, S.; Sano, S.; Katayama, I. Artemin causes hypersensitivity to warm sensation, mimicking warmth-provoked pruritus in atopic dermatitis. J. Allergy. Clin. Immunol. 2012, 130, 671-682. [CrossRef]

94. Heyer, G.; Vogelgsang, M.; Hornstein, O.P. Acetylcholine is an inducer of itching in patients with atopic eczema. J. Dermatol. 1997, 24, 621-625.

95. Tominaga, M.; Ozawa, S.; Tengara, S.; Ogawa, H.; Takamori, K. Intraepidermal nerve fibers increase in dry skin of acetone-treated mice. J. Dermatol. Sci. 2007, 48, 103-111.

96. Fujisawa, H. Discovery of semaphorin receptors, neuropilin and plexin, and their functions in neural development. J. Neurobiol. 2004, 59, 24-33. [CrossRef] [PubMed]

97. Tang, X.Q.; Tanelian, D.L.; Smith, G.M. Semaphorin 3A inhibits nerve growth factor-induced sprouting of nociceptive afferents in adult rat spinal cord. J. Neurosci. 2004, 24, 819-827. [CrossRef] [PubMed]

98. Bigliardi, P.L.; Bigliardi-Qi, M.; Buechner, S.; Rufli, T. Expression of mu-opiate receptor in human epidermis and keratinocytes. J. Investig. Dermatol. 1998, 111, 297-301. [CrossRef] [PubMed]

99. Kumagai, H.; Ebata, T.; Takamori, K.; Muramatsu, T.; Nakamoto, H.; Suzuki, H. Effect of a novel kappa-receptor agonist, nalfurafine hydrochloride, on severe itch in 337 haemodialysis patients: A Phase III, randomized, double-blind, placebo-controlled study. Nephrol. Dial. Transplant. 2010, 25, 1251-1257. [CrossRef] [PubMed]

100. Tominaga, M.; Ogawa, H.; Takamori, K. Possible roles of epidermal opioid systems in pruritus of atopic dermatitis. J. Investig. Dermatol. 2007, 127, 2228-2235. [CrossRef] [PubMed]

101. Hashizume, H.; Horibe, T.; Ohshima, A.; Ito, T.; Yagi, H.; Takigawa, M. Anxiety accelerates T-helper 2-tilted immune responses in patients with atopic dermatitis. Br. J. Dermatol. 2005, 152, 1161-1164. [CrossRef]

102. Hashiro, M.; Okumura, M. The relationship between the psychological and immunological state in patients with atopic dermatitis. J. Dermatol. Sci. 1998, 16, 231-235. [CrossRef] 
103. Smolensky, M.H.; Portaluppi, F.; Manfredini, R.; Hermida, R.C.; Tiseo, R.; Sackett-Lundeen, L.L.; Haus, E.L. Diurnal and twenty-four hour patterning of human diseases: Acute and chronic common and uncommon medical conditions. Sleep Med. Rev. 2015, 21, 12-22. [CrossRef]

104. Hashiramoto, A.; Yamane, T.; Tsumiyama, K.; Yoshida, K.; Komai, K.; Yamada, H.; Yamazaki, F.; Doi, M.; Okamura, H.; Shiozawa, S. Mammalian clock gene Cryptochrome regulates arthritis via proinflammatory cytokine TNF-alpha. J. Immunol. 2010, 184, 1560-1565. [CrossRef]

105. Nakamura, Y.; Harama, D.; Shimokawa, N.; Hara, M.; Suzuki, R.; Tahara, Y.; Ishimaru, K.; Katoh, R.; Okumura, K.; Ogawa, H.; et al. Circadian clock gene Period2 regulates a time-of-day-dependent variation in cutaneous anaphylactic reaction. J. Allergy Clin. Immunol. 2011, 127, 1038-1045. [CrossRef] [PubMed]

106. Takita, E.; Yokota, S.; Tahara, Y.; Hirao, A.; Aoki, N.; Nakamura, Y.; Nakao, A.; Shibata, S. Biological clock dysfunction exacerbates contact hypersensitivity in mice. Br. J. Dermatol. 2013, 168, 39-46. [CrossRef] [PubMed]

107. Mizutani, H.; Tamagawa-Mineoka, R.; Minami, Y.; Yagita, K.; Katoh, N. Constant light exposure impairs immune tolerance development in mice. J. Dermatol. Sci. 2017, 86, 63-70. [CrossRef] [PubMed]

C 2020 by the authors. Licensee MDPI, Basel, Switzerland. This article is an open access article distributed under the terms and conditions of the Creative Commons Attribution (CC BY) license (http://creativecommons.org/licenses/by/4.0/). 